\title{
Glycogen Metabolism of Human Diploid Fibroblast Cells in Culture. I. Studies of Cells from Patients with Glycogenosis Types II, III, and V
}

\author{
Salvatore DiMauro ${ }^{[39]}$, Lewis P. Rowland, and William J. Mellman \\ Departments of Neurology, Pediatrics, and Human Genetics, University of Pennsylvania, Philadelphia, Pennsylvania, USム
}

\section{Extract}

Glycogen synthetase, phosphorylase, debrancher, and acid maltase activities were measured in fibroblasts from normal subjects and from five patients with three different forms of glycogen storage disease. Acid maltase was absent in fibroblasts from two patients with glycogenosis type II, debrancher activity was decreased in fibroblasts from two patients with glycogenosis type III, and phosphorylase activity was normal in fibroblasts from one patient with glycogenosis type $V$.

Fibroblasts from patients with glycogenosis types $I I$ and III accumulated more glycogen than normal cells; glycogen concentrations were about twice normal 10 days after subculture. In both types of mutant cells, glucose starvation was followed by rapid utilization of glycogen. Effective metabolism of glycogen in cells devoid of acid maltase activity makes the role of this enzyme uncertain.

\section{Speculation}

Glycogen is stored excessively in cultured skin fibroblasts from patients with glycogenosis types II (lack of acid maltase) and III (debrancher deficiency). The ready mobilization of glycogen in glycogenosis type II cells challenges the postulated lysosomal mechanism of this disease, or indicates that this in vitro system is not exactly comparable with the in vivo situation.

\section{Introduction}

Human fibroblasts in culture have been used increasingly to investigate genetic diseases [23]. A particular advantage of this in vitro system is the opportunity to study the dynamics of cell macromolecules in mutant states. This study examines the concentration of glycogen in cells from patients with three forms of glycogen storage disease.

\section{Materials and Methods}

\section{Cell Cultures and Preparation of Cell Lysates}

Human fibroblast cell cultures were derived from skin biopsies of 18 individuals. With one exception they were initially propagated in the cytogenetic laboratories of Children's Hospital of Philadelphia. Control cell lines were obtained from chromosomally normal, healthy parents of children with cytogenetic and metabolic disorders (UPG70-9, 70-14, 68-32, 71-15, 7110 [29]), from children with isolated cardiac (UPG71-3) or surgical (UPG69-21) lesions, and from patients with a variety of metabolic and cytogenetic disorders (UPG68-33, 68-38, 70-16, 68-3, 71-36, CCL76). The cell lines from patients with glycogen storage diseases were from two infants with Pompe's disease (glycogenosis type II, lack of acid maltase; one was biopsied here (UPG68-42), the other was supplied by Dr. Rody Cox from a culture established in his laboratory); from two 
children with limit dextrinosis (glycogenosis type III, lack of debrancher system (UPG71-12, 69-29)); and from one 18-year-old youth with McArdle's disease (glycogenosis type $V$, lack of muscle phosphorylase (UPG70-7)).

The cells were in the phase of uniform growth ("phase II" [14]) and were passaged routinely after they had reached confluency in glass milk dilution or l-liter Blake bottles. The medium, unless otherwise noted in d sscriptions of individual experiments, contained Eagle's minimal essential components [30] with glucose, $100 \mathrm{mg} / 100 \mathrm{ml}(\mathrm{w} / \mathrm{v})$, supplemented with $10 \%(\mathrm{v} / \mathrm{v})$ fetal calf serum [30], and chlortetracycline [31], $50 \mu \mathrm{g} /$ $\mathrm{ml}$. Periodic tests of cell cultures were performed for mycoplasma contamination and only negative cells were used in the data reported [13].

When cells were harvested for glycogen determinations or enzyme assays, the cell monolayer surface was washed once with phosphate buffered saline, $0.15 \mathrm{M}$, $\mathrm{pH} 7.4$ (PBS), then $0.25 \%(\mathrm{w} / \mathrm{v})$ trypsin was layered over the monolayer surface for $1 \mathrm{~min}$ and decanted. When the cells detached (5-10 $\mathrm{min})$ they were suspended in PBS, counted in a standard hemocytometer, centrifuged at $600 \times g$ for $10 \mathrm{~min}$, and the pelleted cells lysed by freezing and thawing in distilled water.

For glycogen determination, lysates contained 5-10 $\times 10^{6}$ cells $/ \mathrm{ml}$. For glycogen synthetase assay, the cell concentration was in the range of $10-20 \times 10^{6}$ cells/ $\mathrm{ml}$, for phosphorylase and debrancher assays, 20-30 $\times$ $10^{6}$ cells $/ \mathrm{ml}$. After lysis, preparations were centrifuged at $1,500 \times g$ for $15 \mathrm{~min}$ and the supernatant solution was used for analysis.

Glycogen was measured as glucose after digestion with Diazyme [32], a mixture of glucosidases from Aspergillus niger capable of quantitatively converting glycogen to glucose. Aliquots of cell lysates $(0.25 \mathrm{ml})$ were boiled for $2 \mathrm{~min}$, cooled, and incubated at $37^{\circ}$ for $1.5 \mathrm{hr}$ with $0.25 \mathrm{ml}$ Diazyme, prepared in $0.1 \mathrm{M}$ phosphate buffer, $\mathrm{pH} 6.0$, as described by Johnson and Fusaro [19]. Control samples were incubated with buffer alone. After precipitation with $0.3 \mathrm{M} \mathrm{Ba}(\mathrm{OH})_{2}$ and $0.3 \mathrm{M} \mathrm{ZnSO}_{4}(0.5 \mathrm{ml}$ of each), the glucose produced was measured by glucose oxidase [33] in $0.1-0.25$ ml supernatant.

Most glycogen determinations were carried out immediately after preparation of the cell lysates. In some cases the lysates were frozen and stored for several days at $-20^{\circ}$, without detectable loss of glycogen.

Protein [22] and DNA [26] were assayed in samples of cell suspensions. Protein determinations are therefore expressions of total cell protein, and not of cell supernatants as used elsewhere to quantitate glycogen contents [8].

\section{Enzyme Assays}

Acid maltase ( $\alpha$-D-glucoside glucohydrolase, EC. 3.2 .1 .20 ) activity was measured essentially by the method of Hers and Von Hoof [16]. The assay medium contained, in a final volume of $0.15 \mathrm{ml}: 0.14 \%$ maltose, $33 \mathrm{~mm}$ acetate buffer, $\mathrm{pH} 4.0$, and $0.05 \mathrm{ml}$ cell lysate. In studies of acid maltase activity at different $\mathrm{pH}$ values, $33 \mathrm{~mm}$ citrate buffer was used instead of acetate. After 4 hr at $37^{\circ}$, the reaction was stopped by placing the tube in boiling water for $2 \mathrm{~min}$. After cooling, $1 \mathrm{ml}$ glucose oxidase reagent [33] was added and the tubes were incubated for $1 \mathrm{hr}$ at $37^{\circ}$. The reaction was stopped by addition of $0.5 \mathrm{ml} 2 \mathrm{~N} \mathrm{HCl}$, the mixture was centrifuged and filtered through glass wool, and the optical density measured at $400 \mathrm{~nm}$.

Debrancher (amylopectin 6-glucanohydrolase, EC. 3.2.1.9) activity was measured as ${ }^{14} \mathrm{C}$-glucose incorporation into glycogen [7]. The reaction mixture contained, in a final volume of $0.3 \mathrm{mI}: 25 \mathrm{~mm}$ histidineHCI buffer ( $\mathrm{pH} 6.5$ ), $30 \mathrm{mg}$ shellfish glycogen, $7.5 \mathrm{~mm}$ U. ${ }^{14} \mathrm{C}$-glucose $(0.4 \mu \mathrm{Ci} / \mu \mathrm{mol})$, and $0.09 \mathrm{mI}$ fibroblast lysate. At zero time and after incubation at $37^{\circ}$ for 15 , 30 , and $60 \mathrm{~min}, 0.05-\mathrm{ml}$ aliquots were spotted on filter paper discs (Whatman no. 5); the discs were washed twice ( 45 and $10 \mathrm{~min}$ ) in $66 \%$ ethanol and once $(5$ $\min )$ in acetone and were dried and counted in a Beckman LS-150 scintillation counter [34], with $0.5 \% 2,5$ diphenyloxazole in toluene as scintillation mixture.

UDPG-glycogen synthetase (UDP-glucose: $\alpha$-1,4-glucan, $\alpha$-4-glucosyltransferase, EC. 2.4.1.11) was assayed by measuring the incorporation of labeled UDP-glucose into glycogen at $37^{\circ}$ [27]. The reaction mixture had the following composition, in $0.15 \mathrm{ml}$ : $50 \mathrm{~mm}$ Tris-HCl (pH 7.8), 5 mm EDTA, $15 \mathrm{mg}$ shellfish glycogen, $6.7 \mathrm{~mm}$ UDP-14 C-glucose $(0.05 \mu \mathrm{Ci} / \mu \mathrm{mol}), 6.7 \mathrm{~mm}$ glucose 6-phosphate, and $0.05 \mathrm{ml}$ fibroblast lysate. At zero time and after $10 \mathrm{~min}$ of incubation at $37^{\circ}, 0.05$ $\mathrm{ml}$ aliquots were spotted on filter paper discs (Whatman no. 5). The discs were washed and counted as described for the assay of debrancher.

Phosphorylase $(\alpha-1,4$-glucan:orthophosphate glucosyltransferase, EC. 2.4.1.1). The activity was measured spectrophotometrically in terms of NADP reduced [21]. The assay system contained, in a final volume of $1 \mathrm{ml}: 20 \mathrm{~mm}$ Na-phosphate buffer ( $\mathrm{pH} 7.2$ ), 2 mм $\mathrm{MgSO}_{4}, 1 \mathrm{~mm}$ NADP, $0.1 \%$ shellfish glycogen, 0.8 mm 5'-AMP, 2 units glucose 6-phosphate dehydrogenase, 2 units phosphoglucomutase [35] and $0.1 \mathrm{ml}$ cell 
lysate. The reduction of NADP was followed at 340 $\mathrm{nm}$ in a Beckman DU spectrophotometer [34] by means of a Gilford 2000 recorder [36].

\section{Results}

\section{Glycogen Concentration of Normal and Mutant Cells during Their Growth in Serial Passage (Fig. 1).}

The cells in these experiments were subcultured weekly, when they were fully confluent monolayer cultures at a "split ratio" of $1 / 4$. Although glucose was utilized (see accompanying paper [8]) in the period between medium changes, detectable glucose was continuously present in the culture medium; the medium was completely replaced with fresh medium containing glucose $(100 \mathrm{mg} / 100 \mathrm{ml})$ every $3-4$ days. Under these conditions, glycogen content steadily increased over a 10-day period of observation. At 10 days, the mean cell

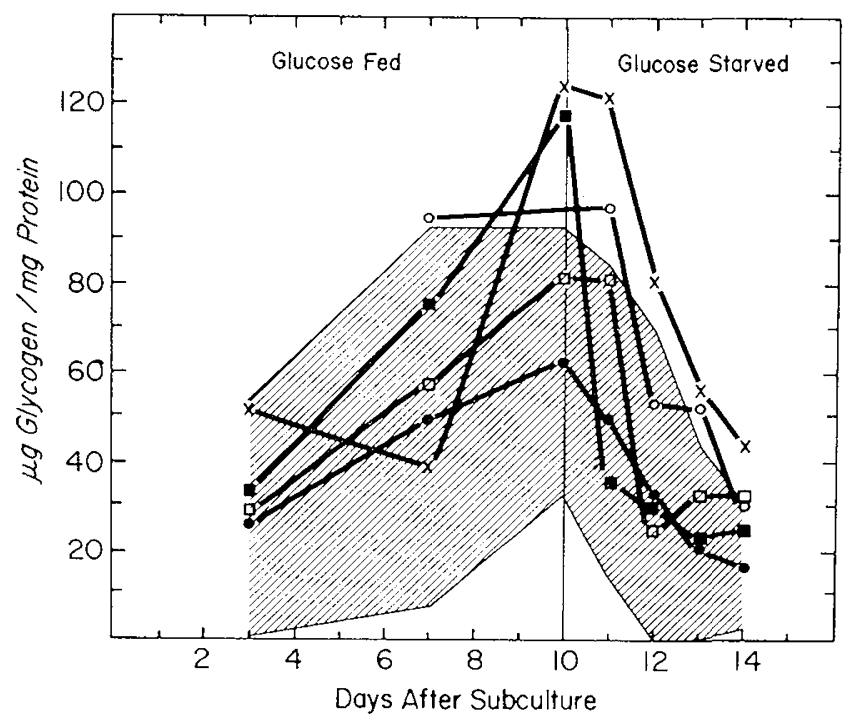

Fig. 1. Glycogen concentrations (expressed as micrograms of glucose per milligram of total cell protein) of control cells and cells from patients with glycogenosis type II $(\bigcirc, \boldsymbol{D})$, type III $(\times)$, and type $V(\square)$. Cells from the same cell strain and passage number were divided after trypsinization into 14 replicate cultures (in milk dilution bottles). The medium was completely replaced 3 , 7 , and 10 days after subculture: at 3 and 7 days with complete medium; at 10 days with medium lacking glucose in the defined portion (some glucose was present in the serum). The cells from two cultures were harvested and pooled on days 3, 7, 10, 11, 12, 13,14 , for glycogen determination.

The data for control cells is based on 11 individual experiments with six different cell strains. The mean $(\bullet)$ glycogen concentrations for the control cells and $\pm 2 \mathrm{SD}$ about the mean (shaded areas) are indicated. The same type of data for cell lines from two different patients with glycogenosis type $I$, and patients with glycogenosis type $I I I$ and type $V$ is supcrimposed on the control values.

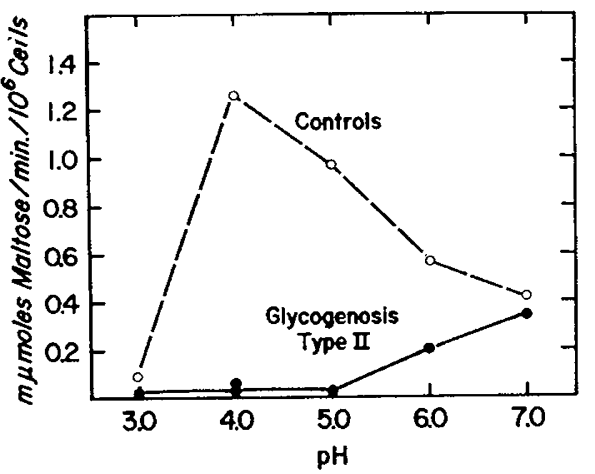

Fig. 2. The effect of $\mathrm{pH}$ on maltase activity of a control cell line and a cell line from a patient with glycogenosis type II.

glycogen was $64.7 \mu \mathrm{g}$ glycogen $/ \mathrm{mg}$ total cell protein. Further increases of glycogen concentration were occasionally observed if these culture conditions were maintained for longer periods, with maximum glycogen concentrations after 14-21 days.

After 10 days of culture in the presence of glucose, if the medium was replaced with medium that contained all the usual components except glucose, the glycogen content of the cells decreased, and after 3-5 days without glucose in the medium, glycogen was barely detectable in the cells of most lines.

Similar experiments were performed with cell lines from patients with glycogenoses types $I I, I I I$, and $V$ (Fig. 1). In fibroblasts from two patients with glycogenosis type II (acid maltase deficiency) and from one patient with type III (debrancher deficiency), glycogen accumulated in excess of the control cell lines.

On the basis of 5 individual studies of two glycogenosis type II cell lines and 14 experiments with six control cell lines, there was a significant difference in the glycogen concentration after 10 days of subculture $(P<0.0 \mathrm{I})$. In the absence of glucose in the medium, these mutant cells utilized glycogen stores at approximately the same rate as normal cells. However, the residual amounts of glycogen, after 4 days of glucose deprivation, were slightly higher than in any control cell line.

Enzymes of Glycogen Metabolism in Normal and Mutant Cells

The deficiency of acid maltase in patients with glycogenosis type II was reflected in the fibroblasts; the enzyme was undetectable at $\mathrm{pH} 4.0$. At $\mathrm{pH} 7.0$, maltase activity in mutant and control cells was similar, but was lower in mutant cells at $\mathrm{pH} 6.0$ (Fig. 2).

Debrancher activity in two cell lines from patients with type III glycogenosis was lower than control cell 
Tabie I. Activities of enzymes of glycogen metabolism in normal and glycogenoses fibroblasts ${ }^{1}$

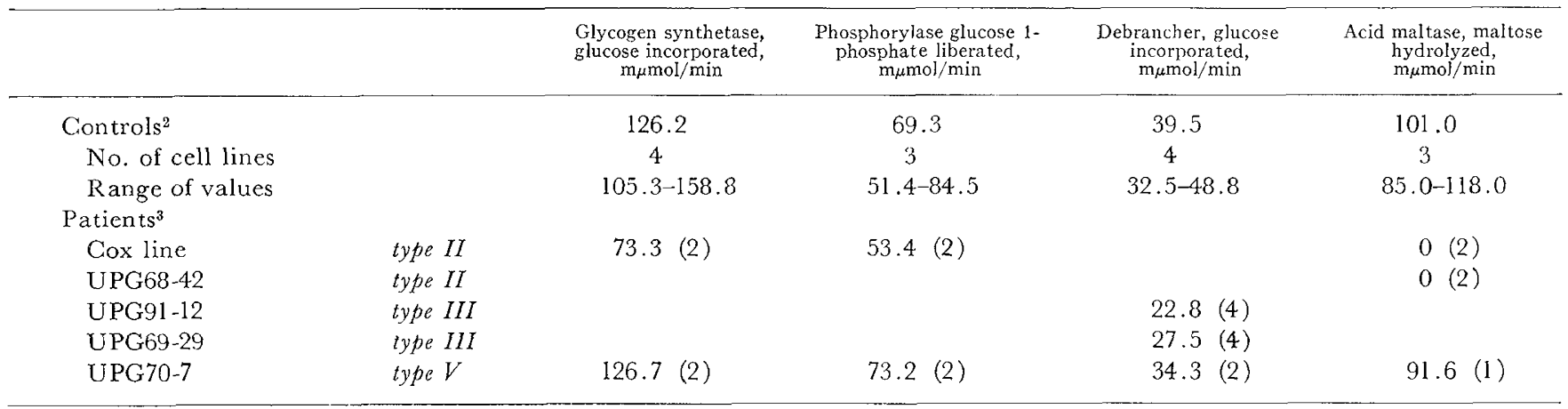

1 All activities are expressed per milligram of DNA.

${ }^{2}$ Ranges of values refer to mean values of different lines. Number of determinations: synthetase, 16; phosphorylase, 7; debrancher, 12; acid maltase, 3.

For the mutant cells, the number of determinations is in parentheses.

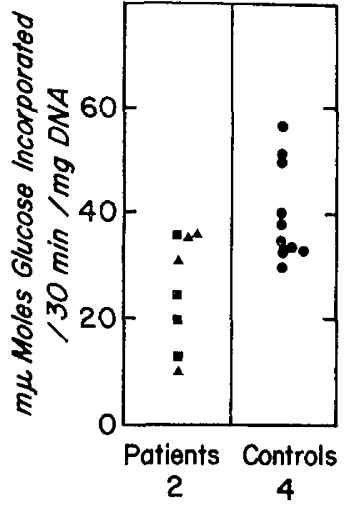

Fig. 3. Debrancher activity of control cells $(\bullet)$ and of cells from two patients with glycogenosis type III $(\mathbf{\square}, \mathbf{A})$.

lines (Table I), only slightly less than some controls but about $66 \%$ of control mean activity. In liver and muscle of the same patients, in contrast, debrancher activity was less than $10 \%$ of normal. There was considerable variation in different determinations of the same mutant cell lines, some essentially normal, others as low as one-third of the lowest normal activity (Fig. 3).

Phosphorylase activity (Table I), absent in skeletal muscle of a patient with glycogenosis type $V$, was normal in his fibroblasts.

\section{Discussion}

Cells cultures from human skin store glycogen when glucose is present and utilize it when glucose is deleted from the medium. These dynamics have been studied with cell lines from controls and patients with glyco- gen storage diseases. These studies suggest that glycogenoses type II and III are expressed under appropriate conditions in cells from affected individuals. Such cell lines can be used, therefore, to improve our understanding of the pathogenesis of the diseases and to evaluate approaches to therapy.

\section{Glycogenosis type II: (Acid Maltase Deficiency)}

Glycogen accumulated in fibroblasts from glycogenosis type $I I$ patients more than in control cells after several days of culture. The highest levels in fibroblasts were about 3 times more than normal, in contrast to the 10-fold increases in other tissues in the same patients. Similar results in fibroblasts were reported by Brown and Brown [2], who found that the half-life of the polysaccharide was about 3 times normal. By adding trehalose, a noncompetitive inhibitor of acid maltase, to the medium of culture for normal fibroblasts, they induced changes in glycogen metabolism similar to the mutant cells.

This pattern is consistent with the absence of acid maltase in cultured fibroblasts of affected children reported here and by other investigators studying this disease $[2,5,6,18,24,25]$. Hug et al. [18] provided morphologic evidence of intralysosomal accumulation of glycogen in fibroblasts. However, we found that when mutant cells were starved of glucose, glycogen was utilized at the same rate, and almost to the same extent, as in normal fibroblasts. These findings are difficult to reconcile with the classical view of Iysosomal diseases [15] of which this was the prototype. The accumulated substrate should be sequestered within lysosomes and not available to extralysosomal enzymes. 
Glucose starvation may somehow have "labilized" the lysosomes and made the accumulated glycogen available to extralysosomal enzymes. This seems unlikely, however, because a massive breakdown of lysosomes should cause cell degeneration and death, whereas the mutant fibroblasts were viable after glycogen depletion and, if fresh medium was added, resumed glycogen synthesis. Excess glycogen may accumulate in glycogenosis type II fibroblasts not only within lysosomes but also free in the cytoplasm, as observed in many other tissues [3, 12, 17]. Preliminary morphologic observations indicate that this is true also of fibroblast cells in culture [11]. The mechanism of accumulation of extralysosomal glycogen is still obscure, but this fraction of the polysaccharide may be more easily degraded by extralysosomal enzymes when the cells are grown in glucose-depleted media. However, the degree of glycogen utilization we observed is difficult to explain, unless only a proportion of the excess glycogen accumulates within lysosomes, or the lack of acid maltase is not the only expression of this genetic disease.

\section{Glycogenosis type III: Debrancher System Defect}

The higher levels of glycogen found in this study in cells from a patient with type III glycogenosis are consistent with the notion that the enzyme defect is, at least partially, expressed by fibroblast cells in culture. On the other hand, the utilization of glycogen by glucose-starved cells was much greater than expected if the enzyme were functionless in the cells; the mutant enzyme presumably has at least partial function in the cultured cells.

In this study, the activity of debrancher system enzymes in fibroblasts of patients with type III glycogenosis was only slightly decreased, about $58 \%$ of the normal mean in cells from one patient and $70 \%$ of normal in the other. In cells from the only other patient so studied, Justice et al. [20], using essentially the same assay, recorded activity between $8 \%$ and $25 \%$ of the normal mean. In affected tissues, enzyme activity is usually less than $10 \%$ of normal as it was in liver and muscle of these patients. The decreased activity in these fibroblasts seemed to be functionally significant, for we found slightly increased accumulation of glycogen; in another patient's fibroblasts, Brown and Brown [2] found that the accumulated polysaccharide had the abnormally short outer chains that characterize other tissue stores. Similarly, variable activities have been recorded in leucocytes; debrancher activity is low in some patients $[4,10,28]$, normal in others [1].

\section{Glycogenosis type V: Muscle Phosphorylase Deficiency}

Glycogen accumulation and utilization as well as phosphorylase activity were normal in fibroblasts from a patient with glycogenosis type $V$. Similar results were also reported by Dreyfus and Alexandre [9]. They also found that phosphorylase protein from normal fibroblasts was immunologically distinct from muscle phosphorylase. Whether the phosphorylase of cultured cells is similar to liver phosphorylase and would therefore reflect genetically determined abnormalities of liver phosphorylase is not known.

\section{Summary}

Cultures of human skin fibroblasts express the enzyme defect in glycogenoses type II and III but not in glycogenosis type $V$. Mutant cells accumulate more glycogen than normal cells. However, glycogen is mobilized in a similar manner by both mutant cell types when the cells are incubated in glucose-free medium. This is particularly interesting in glycogenosis type $I I$ cells, because they have no detectable acid maltase activity. The mobilization of glycogen in glycogenosis type II fibroblasts remains to be explained.

\section{References and Notes}

1. Brandr, I. K., and Deluca, V. A.: Type III glycogenosis: A family with an unusual tissue distribution of the enzyme lesion. Amer. J. Med., 40: 799 (1966).

2. Brown, B. I., ANd Brown, D.: The experimental production of glycogen storage in cultured human fibroblasts. Biochem. Biophys. Commun., 46: 1292 (1972).

3. CardifF, R. D.: A histochemical and clectron microscopic study of skeletal muscle in a case of Pompe's disease (Glycogenosis type II). Pediatrics, 37: 249 (1966).

4. Chayoth, R., Moses, S. W., and Sternitz, K.: Debrancher enzyme activity in blood cells of families with type III glycogen storage disease: A method for diagnosis of heterozygotes. Israel J. Med., 3: 422 (1967).

5. Dancis, J., Hutzler, J., Lynfield, J., And Cox, R. P.: Absence of acid maltase in glycogenosis type II (Pompe's disease) in tissue culture. Amer. J. Dis. Child., 117: 108 (1969).

6. Dimauro, S., Mellman, W. J., Oskx, F. A., and Baker, L.: Glycogen and hexose metabolism in fibroblast cultures from galactosemic and glycogenosis type II patients. Pediat. Res., 3: 368 (1969).

7. Dimauro, S., Trojaborg, W., Gambetti, P. L., and Rowland, L. P.: Binding of enzymes of glycogen metabolism to glycogen in skeletal muscle. Arch. Biochem. Biophys., 144: 413 (1971).

8. Dimauro, S., and Melliman, W. J.: Glycogen metabolism of human diploid fibroblast cells in culture. II. Factors influencing glycogen concentration. Pediat. Res., 9: 745 (1973).

9. Dreyfus, J. C., And Alexandre, Y.: Immunological studies on glycogen storage diseases type III and V. Demonstration of 
the presence of an immunoreactive protein in one case of muscle phosphorylase deficiency. Biochem. Biophys. Res. Commun., 44: 1364 (1971).

10. Esmann, V., Hoboltry, N., And Jorgensen, J. I.: Heredity of leukocyte phosphorylase and amylo-1,6-glucosidase deficiency. J. Pediat., 74: 90 (1969).

11. Gambetti, P. L.: Personal communncation.

12. Gambetti, P. L., DiMauro, S., and Baker, L.: Nervous system in Pompe's disease. J. Neuropathol. Exp. Neurol., 30: 412 (1971).

13. Hayflick, L.: Tissue cultures and mycoplasmas. Texas Rep. Biol. Med., 23: 285 (1965).

14. HAYFLICK, L., AND MoORHEAd, P. S.: The serial cuItivation of human diploid cell strains. Exp. Cell Res., 25, 585 (1961).

15. Hers, H. G.: Inborn lysosomal diseases. Gastroenterology, 48: $625(1965)$.

16. Hers, H. G., AND Van Hoor, F.: Enzymes of glycogen degradation in biopsy material. Methods Enzymol., 8: 525 (1966).

17. Hug, G., Garancis, J. C., Schubert, W. K., and Kaplan, S.: Glycogen storage disease, types II, III, VIII and IX. Amer. J. Dis. Child., 111: 457 (1966).

18. Hug, G., Schubert, W. K., AND Soukup, S.: Ultrastructure and enzymatic deficiency of fibroblast cultures in type II glycogenosis. Pediat. Res., 5: 107 (197I).

19. Johnson, J. A., And Fusaro, R. M.: The quantitative enzymic determination of animal liver glycogen. Anal. Biochem., 15: 140 (1966).

20. Justice, P., Ryan, C., Hsia, D. Y., and Krmpotik, E.: Amylo1,6-glucosidase in human fibroblasts: Studies in type III glycogen storage disease. Biochem. Biophys. Res. Commun., 39: $301(1970)$.

21. Layzer, R. D., Rowland, L. P., and Ranney, H. M.: Muscle phosphofructokinase deficiency. Arch. Neurol., 17: 512 (1967).

22. Lowry, O. H., Rosebrough, N. J., Farr, A. L., and Randall, R. J.: Protein measurement with the Folin phenol reagent. J. Biol. Chem., 193: 265 (1951).

23. Mrllmann, W. J., and Cristofalo, V. J.: Human diploid cell cultures: Their usefulness in the study of genetic variations in metabolism. In: Growth, Nutrition and Metabolism in Cells in Culture. Vol. 1, p. 327. (Academic Press, New York, 1972).
24. Nitowsky, H. M., And Grunfeld, A.: Lysosomal $\alpha$-glucosidase in type II glycogenosis: Activity in lcukocytes and cell cultures in relation to genotype. J. Lab. Clin. Med., 69: 472 (1967).

25. SAlafsky, I. S., AND NAdLer, H. L.: Alpha-1,4-glucosidase activity in Pompe's disease. J. Pediat., 79: 794 (1971).

26. Tedesco, T. A., and Mellanan, W. J.: Desoxyribonucleic acid assay as a measure of cell number in preparations from monolayer cell cultures and blood leukocytes. Exp. Cell Res., 45: 230 (1966).

27. Thomas, J. A., Schlender, K. K., and Larner, J.: A rapid filter paper assay for UDP-glucose-glycogen glucosyltransferase, including an improved biosynthesis of UDP-14 C-glucose. Anal. Biochem., 25: 486 (1968).

28. Williams, C., And Field, J. B.: Studies in giycogen storage disease. III. Limit dextrinosis: A genetic study. J. Pediat., 72: 214 (1968).

29. For the studies involving human subjects reported in this paper, written informed consent has been obtained in accordance with the provisions of the Declaration of Helsinki.

29. Laboratory numbers refer to specific cell lines.

30. Flow Labs, Inc., Rockville, Md.

31. Aureomycin, Lederle Labs., Pearl River, N. Y.

32. Diazyme, Miles Labs, Inc., Kanakee, III.

33. Glucostat, Worthington Biochemical Corporation, Freehold, N. J.

34. Beckman Instruments, Inc., Fullerton, Calif.

35. Bochringer Manheim Corporation, New York, N.Y.

36. Gilford Instrument Labs, Inc., Oberlin, Ohio.

37. This work was presented in part at the 79th Annual Meeting of the American Pediatric Society, Atlantic City, May 1969 [6].

38. This research was supported by Grants nos. HD-00588, HD15545, and NS-08075, United States Public Health Service, and a grant from the Muscular Dystrophy Associations of America.

39. Requests for reprints should be addressed to: SALvarore DrMauro, M.D., Department of Neurolgy, University of Pennsylvania School of Medicine, 429 Johnson Pavilion, 36th St. and Hamilton Walk, Philadelphia, Pa. 19174 (USA).

40. Accepted for publication April 10, 1973. 